Al-Madrasah: Jurnal Ilmiah Pendidikan Madrasah Ibtidaiyah

Vol. 5, No. 1, 2020

DOI 10.35931/am.v5i1.330

P-ISSN: 2620-5807; E-ISSN: 2620-7184

\title{
PENGEMBANGAN KETERAMPILAN MEMBACA SISWA MADRASAH IBTIDAIYAH KELAS RENDAH MENGGUNAKAN PICTURE WORD INDUCTIVE MODEL
}

\author{
Muhammad Majdi \\ Dosen, Sekolah Tinggi Ilmu Al-Quran (STIQ) Amuntai, Kalimantan Selatan \\ Email: Muhammadmajdi755@gmail.com
}

\begin{abstract}
Abstrak
Keterampilan membaca termasuk dari empat komponen keterampilan dalam mata pelajaran Bahasa Indonesia yaitu keterampilan menulis, membaca, berbicara, dan menyimak. Penelitian ini berfokus pada keterampilan membaca jenis keterampilan membaca permulaan pada kelas rendah. Karena dilapangan masih ditemukan sebagian kecil peserta didik yang belum terampil dalam membaca, oleh karena itu strategi Picture Word Inductive Model adalah salah satu langkah terapi yang cukup sederhana namun efektif diterapkan kepada peserta didik tersebut, baik itu bagi peserta didik yang memiliki kemampuan membaca rendah sampai kepada kemampuan sedang dan tinggi. Penelitian ini menggunakan penelitian kualitatif bersifat induktif. Subjek dalam penelitian ini adalah wali kelas $2 b$ MIS Al Islamiyah Bangkar yang berinisial MIY dan 32 siswa kelas 2b. Berdasarkan hasil penelitian bahwa pengembangan keterampilan membaca menggunakan Picture Word Inductive Model dapat mengembangkan kualitas pembelajaran keterampilan membaca permulaan bagi kelas 2 MIS Al Islamiyah Bangkar, dengan tahapan-tahapan sebagai berikut 1) pengenalan gambar guru menggunakan konsep gambar pop up. 2) Peserta didik mengidentifikasi gambar. 3) Review kata bergambar secara audio dan visual. 4) Menyusun kata dan kalimat, bersama mengembangkan kata menjadi sebuah kalimat sederhana. Jadi hasilnya peserta didik yang memiliki keterampilan membaca rendah mulai berangsur-angsur membaik dengan tindak lanjut secara continue atau berkelanjutan disetiap pembelajarannya. Sedangkan peserta didik yang sudah memiliki keterampilan membaca sedang dan tinggi dapat mengembangkannya lebih baik lagi.
\end{abstract}

Kata Kunci: Pengembangan Keterampilan Membaca, Siswa Madrasah Ibtidaiyah Kelas Rendah, Picture Word Inductive Model

\section{A. Pendahuluan}

Pada dasarnya keterampilan membaca termasuk dari empat komponen keterampilan dalam mata pelajaran Bahasa Indonesia yaitu keterampilan menulis, membaca, berbicara, dan menyimak. ${ }^{1}$ Golongan yang disebut kelas rendah dalam hal ini pada SD/MI yaitu kelas 1,2, dan 3. Jenis membaca di kelas rendah

\footnotetext{
${ }^{1}$ Henry Guntur Tarigan, Menulis: sebagai Suatu Keterampilan Berbahasa (Bandung: Angkasa, 1986), h. 1.
} 
sebagaimana disebut dalam buku Siti Anisatun Nafi'ah yaitu membaca permulaan, membaca teknik, membaaca dalam hari, dan membaca nyaring dengan tujuan untuk membina kemampuan peserta didik dalam hal mekanisme membaca, membina gerak mata dari kiri ke kanan, dan membaca kata-kata dan kalimatkalimat pendek. $^{2}$ Fokus penelitian ini adalah mengenai keterampilan membaca permulaan pada kelas rendah.

Membaca permulaan yaitu pengajaran yang diterapkan kepada peserta didik tingkat permulaan sekolah dasar. Bertujuan untuk menumbuhkan dasar mekanisme membaca, seperti kemampuan mengasosiasikan huruf dengan bunyi-bunyi bahasa yang diwakilinya dan membina gerakan mata membaca dari kiri ke kanan. ${ }^{3}$

Fahrurrozi dalam penelitiannya menjelaskan tentang membaca permulaan, bahwa mengenai kemampuan membaca permulaan adalah kompetensi yang dimiliki oleh peserta didik dalam melafalkan huruf dan angka dengan penggunaan bahasa yang nyaring dan jelas didengar. Oleh karenanya, kompetensi dalam membaca permulaan memelurkan pencapaian kemampuan peserta didik dalam melafalkan huruf, kata, dan kalimat. Karena membaca permulaan termasuk pembelajaran bahasa Indonesia di SD yang sangat penting diajarkan ketika peserta didik memasuki kelas awal yang mana seorang anak dituntut untuk mengubah rangkaian-rangkaian huruf menjadi rangkaian-rangkaian bunyi yang bermakna serta melancarkan teknik membaca untuk memberikan dasar kemampuan menuju tahap membaca lanjut di kelas berikutnya. Guru perlu menguasai berbagai macam metode mengajar membaca permulaan seperti metode SAS. Dengan adanya pemahaman dan penerapan metode membaca yang tepat, maka pembelajaran akan berjalan lebih efektif sehingga tujuan yang diinginkan dapat berjalan dengan baik seperti menjadikan peserta didik mampu membaca huruf, kata, dan kalimat. Selain itu, dengan memahami karakteristik peserta didik kelas rendah guru akan memahami dan mampu menerapkan kebutuhan belajar bagi siswanya. ${ }^{4}$

Calhoun mengembangkan Picture Word Inductive Model, menggunakan foto berisikan objek yang dikenal oleh peserta didik untuk menghasilkan kata-kata dari anak-anak. Pembelajaran PWIM ini membantu peserta didik mendeteksi beberapa kosa kata dengan apa yang mereka baca dan lihat, serta kosakata yang ditulis, dan juga dapat menemukan konsep fonetik dan struktural yang muncul dalam katakata. Tujuan menggunakan Picture Word Inductive Model yaitu untuk pengembangan kosakata, konsep tentang kata-kata, kalimat dan struktur paragraf. kelebihan menggunakan model pembelajaran ini yaitu dapat membantu membangun kosakata dan kemampuan menulis. ${ }^{5}$ Pada penelitian Lalu Kasiran langkah-langkah dalam pembelajaran Picture Word Inductive Model adalah sebagai berikut: (1) guru

\footnotetext{
${ }^{2}$ Siti Anisatun Nafi'ah, Model-Model Pembelajaran Bahasa Indonesia di SD/MI (Yogyakarta: Ar-Ruzz Media, 2018), h. 51

${ }^{3}$ Solchan T. W.. dkk, Pendidikan Bahasa Indonesia di SD (Banten: Universitas Terbuka Press, 2014), h. 8.5.

${ }^{4}$ Fahrurrozi, Pembelajaran Membaca Permulaan di Sekolah Dasar, Jurnal Ilmiah PGSD Vol. X No.2 Oktober 2016.

${ }^{5}$ Lalu kasiran, Penerapan Strategi Picture Word Inductive Model Guna Meningkatkan Hasil Belajar Dalam Menyusun Teks Deskriptif Berbahasa Inggris Bagi Siswa Kelas Vii/A Smp Negeri 3 Praya Tahun Ajaran 2014/2015, Jurnal Media Bina Ilmiah, Vol.12, No.11 Juni 2018.
} 
Muhammad Majdi : Pengembangan Keterampilan Membaca Siswa Madrasah Ibtidaiyah Kelas Rendah Menggunakan Picture Word Inductive Model

mengadakan gambar yang sering ditemui peserta didik melalui monitor, (2) guru mengadakan juga kertas yang terdapat gambar dan garis yang mengarah dari objek gambar yang berisi kata yang sesuai dengan objek, (3) peserta didik mengenali serta memberi nama kegiatan yang ada dalam gambar, (4) peserta didik menghubungkan objek dengan kata-kata yang ada di samping gambar yang telah tertulis, (5) guru melatih peserta didik mengeja serta membaca kata-kata tersebut, dan (6) peserta didik menulis kata-kata yang telah mereka hafal dari gambar sebelumnya. Dengan demikian konsep yang terpenting dari pembelajaran ini yaitu membangun kosa kata dan bentuk-bentuk sintaksis peserta didik dan dapat menyediakan peralihan dari perkataan menjadi tulisan. ${ }^{6}$

Strategi PWIM diklasifikasikan untuk pembelajaran kelas rendah. Secara umum tujuan membaca di SD kelas rendah dapat dilihat sebagai berikut. 1) mengasosiasikan huruf dengan bunyi-bunyi bahasa yang diwakilinya (yang dilatih adalah membaca teknik dan nyaring). 2) membina gerak mata dari kiri dan kanan. 3) membaca kata-kata dan kalimat-kalimat pendek. ${ }^{7}$

Rangkaian putaran PWIM dalam sebuah pelajaran dari sebuah gambar, yang biasanya berbentuk foto, didalamnya berisi materi-materi, baik elemen-elemen maupun rincian-rincian penting, yang meliputi semua hal yang dapat digunakan siswa untuk mendeskripsikannya dengan menggunakan bahasa pendengaran dan percakapan. Siswa mempelajari gambar tersebut kemudian "membongkar" kata-kata. Hal ini berarti siswa mengidentifikasi segala objek yang mereka lihat dalam gambar, dan guru menggambar sebuah garis dari objek-objek itu hingga menuju kertas yang ada di belakang gambar yang sudah berisi katakata dan frasa-frasa yang sesuai dengan objek-objek tersebut, mengucapkan kembali kata/frasa tersebut, menulis, dan mengeja kata atau frasa itu dengan keras. Siswa mengulangi kembali mengeja dan membaca kata itu. $^{8}$

Tahap PWIM berikutnya melibatkan guru untuk mempersiapkan beberapa kartu kata untuk siswa mengecek apakah mereka langsung bisa mengenal kata-kata tersebut atau justru harus mzn-decoding kata- kata itu terlebih dahulu dengan menggunakan kamus kata bergambar saat menemukan kesulitan. Dengan cara ini, guru akan lebih mudah untuk menilai pengetahuan dan keterampilan siswa. Saat siswa mulai membaca katakata, tahap selanjutnya sudah bisa diterapkan: siswa mengklasifikasi kata-kata dalam bentuk fonetik, struktural, atau isi; mengilustrasikan kategori-kategori; menjelaskan alasan-alasan mengapa menaruh beberapa kartu tertentu dalam tiap-tiap kategori. Aktivitas kategorisasi membutuhkan waktu yang cukup lama selama perputaran PWIM. ${ }^{9}$

Meski demikian, laju pembelajaran dalam sesi perputaran PWIM ini sebenarnya tergantung pada tingkat pembacaan siswa dan materi kurikulum guru, tetapi setelah klasifikasi kata, siswa dapat langsung diminta untuk menghasilkan kalimat fakta tentang gambar tadi. Kata- kata baru dari kalimat-kalimat tersebut

\footnotetext{
${ }^{6}$ Rachmawati, Pengembangan Model Induktif Kata Bergambar Pada Pembelajaran Menulis Permulaan Di Kelas Ii Sd, Sekolah Dasar, Tahun 24 Nomor 2, November 2015.

${ }^{7}$ Solchan T. W.. dkk, Pendidikan Bahasa Indonesia di SD, h. 86.

${ }^{8}$ Bruce Joyce, Models of Teaching: Model-Model Pengajaran (Yogyakarta: Pustaka Pelajar, 2009), h. 156.

${ }^{9}$ Bruce Joyce, Models of Teaching: Model-Model Pengajaran, h. 156.
} 
Muhammad Majdi : Pengembangan Keterampilan Membaca Siswa Madrasah Ibtidaiyah Kelas Rendah Menggunakan Picture Word Inductive Model

mungkin bisa ditampilkan pada "bank kosa kata" siswa, dan aktivitas kategorisasi pun dapat diulang kembali sebentar saja. Setelah siswa membaca kalimat, sesegera mungkin mereka diminta untuk mengklasifikasikannya ke dalam kelompok-kelompok dan membuat alasan-alasan atas klasifikasi yang telah mereka buat. ${ }^{10}$ Lihat digambar 1.

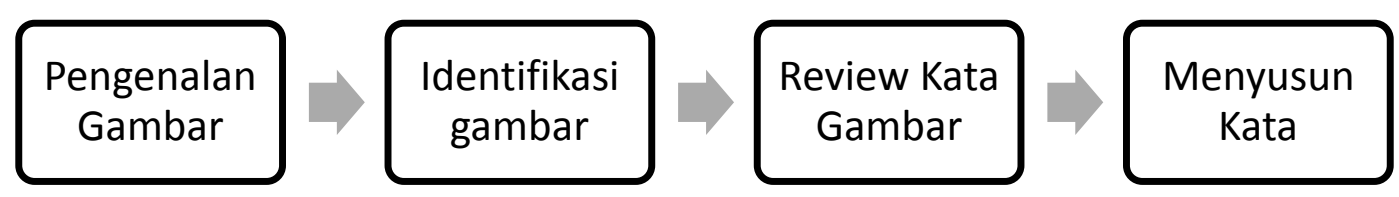

Langkah-langkah strategi diatas secara luas dijabarkan dalam buku Siti Anisatun Nafi'ah dengan judulnya Model-Model Pembelajaran Bahasa Indonesia SD/MI adalah sebagai berikut:

1. Pengenalan gambar. a) Guru memilih sebuah gambar dibuku bahan ajar. Misalnya gambar tentang kumpulan hewan. b) Guru menanyakan kepada peserta didik tentang nama-nama hewan tersebut. c) Peserta didik menjawab pertanyaan.

2. Identifikasi kata bergambar, a) Guru membuat garis lurus pada gambar sesuai dengan nama binatang, b) Guru membuat kartu yang berisikan nama-nama hewan yang ada pada gambar.

3. Review kata bergambar, a) Guru membacakan kartu kata tersebut kepada peserta didik, b) Peserta didik mengikuti ucapan dari guru.

4. Menyusun kata dan kalimat, a) Jika peserta didik sudah mampu membaca dengan benar pada kartu kata, guru selanjutnya menyusun kalimat sederhana dari kartu kata tersebut, b) Kemudian guru menuliskannya dalam papan tulis, c) Guru mengarahkan peserta didik untuk membacanya bersamasama. $^{11}$

Hasil Praobservasi dilapangan bahwa ada sebagian kecil di kelas rendah khususnya kelas 2B di MIS Al Islamiyah Bangkar yang belum terampil dalam membaca, oleh karena itu strategi PWIM adalah salah satu langkah terapi yang cukup sederhana namun efektif diterapkan kepada peserta didik tersebut. Maka dari itu peneliti membuat penelitian yang berjudul Pengembangan Keterampilan Membaca menggunakan Picture Word Inductive Model, secara tidak langsung guru memberikan stimulus kepada peserta didik dengan keterampilan membaca sedang dan tinggi untuk lebih meningkatan keterampilan membacanya dan keterampilan membaca rendah untuk memperbaikinya agar dapat mengasah keterampilan membaca.

\section{B. Metode Penelitian}

Penelitian ini menggunakan penelitian kualitatif, yaitu menggambarkan keadaan yang ada di lapangan. Adapun pendekatan yang digunakan adalah bersifat induktif. Maksudnya, peneliti membiarkan permasalahan-permasalahan muncul dari data atau dibiarkan terbuka untuk interpretasi. Data dihimpun

\footnotetext{
${ }^{10}$ Bruce Joyce, Models of Teaching: Model-Model Pengajaran, h. 156-157.

${ }^{11}$ Siti Anisatun Nafi'ah, Model-Model Pembelajaran Bahasa Indonesia di SD/MI, h. 78-80.
} 
Muhammad Majdi : Pengembangan Keterampilan Membaca Siswa Madrasah Ibtidaiyah Kelas Rendah Menggunakan Picture Word Inductive Model

dengan pengamatan yang seksama, mencakup deskripsi dalam konteks yang mendetil diserta catatan-catatan hasil observasi, wawancara yang mendalam, ${ }^{12}$ Maka data yang akan dikumpulkan nantinya berupa katakata, gambar dan bukan berupa angka. Lokasi penelitian di MIS Al Islamiyah Bangkar Kecamatan Muara Uya Kabupaten Tabalong Provinsi Kalimantan Selatan. Subjek dalam penelitian ini adalah wali kelas $2 \mathrm{~b}$ MIS Al Islamiyah Bangkar yang berinisial MIY dan 32 siswa kelas 2b. Metode analisis data yang digunakan peneliti adalah data kualitatif menurut pendapat Cresswell dengan mengikuti langkah-langkah sebagai berikut: 1). Mengorganisasi dan menyiapkan data yang akan dianalisa, 2). Membaca, memahami, dan melihat semua data yang masuk terkait pengembangan keterampilan membaca siswa madrasah ibtidaiyah kelas rendah menggunakan Picture Word Inductive Model, 3). Membuat koding data-data yang masuk, 4). Menggunakan koding tersebut menjadi bahan dalam membuat deskripsi lanjutan, 5). Menghubungkan antar tema yang terkait, dan 6). Memberikan interpretasi tentang tema dalam penelitian. ${ }^{13}$

\section{Hasil Penelitian Dan Pembahasan}

\section{Deskripsi pembelajaran Picture Word Inductive Model}

Guru malaksanakan pembelajaran Picture Word Inductive Model (PWIM) menggunakan media pop up dengan tujuan untuk mengembangkan keterampilan membaca permulaan yang ditujukan kepada peserta didik MI kelas rendah. Karena keterampilan membaca berpengaruh besar terhadap kegiatan pembelajaran lainnya. Implementasi dari pembelajaran Picture Word Inductive Model dijabarkan sebagai berikut:

\section{a. Pengenalan gambar}

Hasil dari observasi, kegiatan pada awal pembelajaran guru membuka pembelajaran dan menyampaikan tujuan pembelajaran dengan semangat. Setelah itu guru menyiapkan gambar sebagai media utama pada strategi pembelajaran PWIM ini dengan melakukan improvisasi menggunakan gambar $3 \mathrm{~d}$ atau Pop up dan menuliskan nama-nama itu pada papan tulis. Tema gambar yang disiapkan oleh guru adalah kumpulan-kumpulan binatang yaitu anjing, kucing, ayam, dan bebek. Guru juga menyiapkan media berupa kartu kata yang akan dibagikan kepada peserta didik berisikan nama-nama gambar tersebut. Guru menempelkan nomor disetiap gambar agar dapat menyesuaikan dengan urutan pada tulisan papan tulis serta peserta didik dapat sekaligus mengamati tulisannya.

Pada fase pertama yaitu sampai kelas dua, anak memusatkan perhatian pada kata-kata lepas dalam cerita sederhana. Supaya dapat membaca, anak perlu mengetahui sistem tulisan, cara mencapai kelancaran membaca, dan terbebas dari kesalahan membaca. Oleh karena itu anak harus dapat mengintegrasikan bunyi dan sistem tulisan. Pada umur 7 atau 8 tahun, kebanyakan anak-anak telah memperoleh pengetahuan tentang huruf, suku kata, dan kata yang diperlukan untuk dapat membaca. Pengetahuan ini dalam kebanyakan negara

\footnotetext{
${ }^{12}$ Nana Syaodih Sukmadinata, Metode Penelitian Pendidikan, (Bandung: Remaja Rosdakarya,2015), h. 60.

${ }^{13}$ Sugiyono, Metode Penelitian Kualitatif untuk Penelitian yang Bersifat: Eksploratif Interaktif dan Konstruktif ( Bandung: Alfabeta, 2017), h. 162-163.
} 
Muhammad Majdi : Pengembangan Keterampilan Membaca Siswa Madrasah Ibtidaiyah Kelas Rendah Menggunakan Picture Word Inductive Model

diperoleh di Sekolah. ${ }^{14}$ Dalam hal ini guru sudah melakukannya dengan baik yaitu merangsang imajinasinya dengan sebuah gambar pop up dan sebuah kartu kata. Dengan demikian guru dapat mengenalkan huruf dan dapat merangsang rasa ingin tahunya terhadap suku kata pada gambar.

Joko Muktiono menjelaskan Pop Up adalah sebuah buku/sebuah media yang memiliki tampilan gambar yang bisa ditegakkan serta membentuk obyek-obyek yang indah dan dapat bergerak atau memberi efek yang menakjubkan. ${ }^{15}$ Dengan demikian media gambar yang diimprovisasi dalam PWIM ini berupa pop up menjadikan tambahan daya tarik peserta didik terhadap tampuilan yang lebih menarik. Dalam penelitian lain terkait media Pop-Up Book. Pada jurnalnya Andi Irwan Benardi mengungkapkan bahwa rata-rata dari aktivitas peserta didik selama ikut serta dalam pembelajaran menggunakan bantuan media Pop-Up book adalah tinggi dan adanya peningkatan/perkembangan pada semua indikator respon peserta didik terhadap pembelajaran tambah menguatkan bahwa media Pop up book efektif digunakan dalam pembelajaran peserta didik anak usia dini. ${ }^{16}$

Selanjutnya pada tahap pertama ini sesuai hasil observasi, guru melakukan pretest yaitu menanyakan pengetahuan awal peserta didik. Disini guru menanyakan kepada peserta didik secara random nama-nama hewan yang ada pada gambar. Setelah itu peserta didik menjawab dengan antusias.

Jadi pada dasarnya tahap pertama ini guru sudah melaksanakan pembelajarran dengan baik, berupa tambahan improvisasi pada gambar untuk menambah daya minat peserta didik. Kemudian guru mengadakan pretest untuk mengetahui pengetahuan awalnya.

\section{b. Identifikasi kata bergambar}

Pada tahap ini dari hasil observasi, guru membagikan kartu kata berisi nama-nama hewan kepada peserta didik. Kemudian guru meminta kepada peserta didik untuk mengamati hewan-hewan yang ada pada gambar pop up tersebut. Peserta didik dapat melihat nomor pada gambar dan dapat melihat tulisannya dipapan tulis maupun dikartu kata. Pada tahap ini juga guru memberikan tanya jawab secara merata kepada peserta didik dari yang memiliki keterampilan membaca permulaan rendah, sedang, maupun tinggi.

Sesuai dengan pendapat Ramly dalam bukunya menjelaskan tentang Teknik belajar visual eksternal yaitu proses belajar dengan mengoptimalkan penglihatan dengan mengeksplorasikan dunia luar dirinya. Praktisnya bisa menggunakan buku, gambar, komputer, poster dengan tampilan yang menarik. ${ }^{17}$

\section{c. Review kata bergambar.}

Selanjutnya pada tahap ini sesuai hasil pengamatan, guru membacakan kartu kata kepada peserta didik dengan menggunakan suara yang nyaring (reading aloudi). Kemudian Peserta didik mengikuti ucapan guru secara berulang-ulang sambil diminta untuk memperhatikan tulisan/suku katanya.

\footnotetext{
${ }^{14}$ Isah Cahyani, Modul Pembelajaran Bahasa Indonesia (Jakarta: Direktorat Jenderal Pendidikan islam, 2012), h. 69 .

${ }^{15}$ Joko Muktiono, Menumbuhkan Minat baca pada Anak (Jakarta: ElexMedia Komputindo, 2003), h. 65.

${ }^{16}$ Benardi, Andi Irwan. Pendidikan Kesiapsiagaan Bencana Tanah Longsor Untuk Siswa Anak Usia Dini Dengan Metode Dongeng Berbasis Media Pop Up Book Di Paud Dewi Sartika Kecamatan Bergas. Jurnal., Portal Jurnal Elektronik UM: Jurusan Pendidikan Geografi: UM. 2017.

${ }^{17}$ Amir Tengku ramly, Proses Belajar Mengajar (Jakarta: Bumi Aksara, 2004), h. 111.
} 
Muhammad Majdi : Pengembangan Keterampilan Membaca Siswa Madrasah Ibtidaiyah Kelas Rendah Menggunakan Picture Word Inductive Model

Menurut Hisam Zaini Reading aloud atau membaca dengan suara keras yaitu strategi yang dapat membantu peserta didik dalam berkonsentrasi, mengajukan pertanyaan, dan memberikan stimulus peserta didik untuk diskusi. ${ }^{18}$ Reading aloud juga dapat membentuk fokus perhatian secara mental. ${ }^{19}$

Reading Aloud dalam penelitian Hertika Jeniar Litri adalah suatu serangkaian aktivitas yang merupakan bahan bagi guru, peserta didik, maupun pembaca atau pendengar untuk dapat memahami informasi, pikiran, serta perasaan seorang pengarang. Jadi, Reading Aloud dalam hal ini membantu atau menstimulus peserta didik untuk suka membaca dan membantu agar bacaan dapat terfokuskan. Karena di reading aloud guru meminta peserta didik secara berurutan untuk membaca dengan suara yang keras. Makan apabila peerta didik tidak/kurang fokus maka konsekuensinya kebingungan untuk dapat melanjutkan bacaannya. Selain itu disetiap paragraf guru juga akan menanyakan point penting sebagai bahan diskusi. Yang mana berdasarkan hasil penelitian dan pembahasan dari Hertika Jeniar Litri ini memberikan kesimpulan bahwa, implementasi pembelajaran membaca permulaan dengan menggunakan metode Reading Aloud yang diterapkan di kelas II SD Negeri Caturtunggal 6 Depok Sleman Yogyakarta sudah tepat dan sesuai. Keterampilan membaca dengan jelas sudah tergambar pada RRP yang sudah terlampir. Guru juga sudah menerapkan media untuk sarana pendukung dalam kegiatan pembelajaran dan guru sudah memberikan contoh terlebih dahulu bagaimna cara membaca sehingga siswa bisa membaca dengan tepat dan jelas. Pada keterampilan membaca dengan penuh perasaan, guru sudah memberikan catatan-catatan dipapan tulis sehingga memudahkan peserta didik dan secara keseluruhan dapat membacanya. Pada keterampilan membaca tanpa terbata-bata, peserta didik menunjukan bahwa peserta didik sudah lancar dalam membaca. Hal-hal demikian menghasilkan guru dapat memintata peserta didik untuk membaca secara klasikal, kelompok, dan individu karena peserta didik sudah pandai dalam membaca. ${ }^{20}$

Pada tahap ini keterampilan guru untuk mengelola kelas sangatlah diperlukan. Hasil dari observasi cara yang dilakukan guru untuk mengkondisikan kelas yaitu dengan memberikan tepuk dan menyanyi, agar kondisi pembelajaran dapat berjalan dengan kondusif. Dari hasil observasi juga terlihat peserta didik yang memiliki keterampilan membaca rendah mulai terbiasa dan pandai, hal demikian dapat dibuktikan dengan mulai aktifnya peserta didik menjawab pertanyaan-pertanyaan guru pada saat tahap mereview kata dan kalimat pada kata bergambar.

Dari pemaparan diatas guru sudah menerapkan pembelajaran dan mengelola kelas dengan baik hal ini sesuai dengan pendapat Asih dalam bukunya tentang ciri-ciri guru berkualitas yaitu mengelola kelas dengan pengalaman belajar, menggunakan media atau sumber dengan pengelaman belajar dan dapat menciptakan suasana yang menumbuhkan gairah belajar dan meningkatkan prestasi belajar siswa. ${ }^{21}$ hal ini dapat dibuktikan dengan antusias peserta didik dalam mengikuti pembelajaran dan pemahaman atas hal yang

\footnotetext{
${ }^{18}$ Hisyam Zaini, dkk, Strategi Pembelajaran Aktif, (Yogyakarta: Pustaka Insan Madani, 2008) h.43

${ }^{19}$ Ismail SM, Strategi Pembelajaran Agama Islam Berbasis PAIKEM (Pembelajaran Aktif, Inovatif, Efektif, dan Menyenangkan), (Semarang: RaSAIL Media Group, 2008), h. 76

${ }^{20}$ Hertika Jeniar Litri, Implementasi Metode Reading Aloud Dalam Pembelajaran Membaca Permulaan Pada Siswa Kelas 2 SD, Jurnal Pendidikan Guru Sekolah Dasar Edisi 31 Tahun ke-5 2016.

${ }^{21}$ Asih, Strategi Pembelajaran Bahasa Indonesia (Bandung: Pustaka Setia, 2016) h. 185.
} 
Muhammad Majdi : Pengembangan Keterampilan Membaca Siswa Madrasah Ibtidaiyah Kelas Rendah Menggunakan Picture Word Inductive Model

disampaikan oleh guru. Sesuai dengan prinsip-prinsip dalam pembelajaran Bahasa Indonesia menurut Aminuddin yaitu memberikan kesempatan berpartisipasi dalam penggunaan bahasa secara komunikatif dalam berbagai macam aktivitas.

\section{d. Menyusun kata dan kalimat}

Secara sederhana guru dapat memancing peserta didik untuk membuat kalimat secara tidak langsung dengan memberikan kalimat tanya yang diambil dari nama-nama hewan yang sudah disediakan. Yang dilaksanakan guru pada tahap ini bertanya memncing jawaban peserta didik "apa yang sedang dilakukan binatang itu?" peserta didik menjawab "Binatang itu sedang bermain" guru bertanya lagi "dimana binatang itu bermain?" peserta didik menjawab "dihalaman rumah". Kemudian guru menulis dipapan tulis kalimat yang dihasilkan oleh peserta didik. Dilanjutkan arahan guru untuk meminta peserta didik bersama-sama membaca dan mengeja kalimat sederhana. Pembelajaran demikian dapat digunakan secara berulang-ulang dengan gambar yang berbeda atau jenis kalimat pertanyaan berbeda.

Pada tahap ini juga guru mengajak peserta didik untuk berpartisipasi dalam kegiatan pembelajaran, peserta didik juga berani mengutarakan argumennya dengan suara yang jelas dan keras. Pembelajaran akan lebih optimal karena kondisi ini membuat peserta didik dengan keterampilan membaca permulaan sedang dan rendah dapat secara aktif menyuarakan pendapatnya. Dengan demikian dapat mempengaruhi keterampilan membaca permulaan peserta didik mulai mengalami perkembangan.

\section{Penilaian pembelajaran Picture Word Inductive Model}

Sesuai dengan prinsip-prinsip dalam pembelajaran Bahasa Indonesia menurut Aminuddin yaitu pemberian kesempatan berpartisipasi dalam penggunaan bahasa secara komunikatif dalam berbagai macam aktivitas dan pemberian umpan balik yang tepat berkaitan dengan kemajuan mereka ${ }^{22}$

Untuk dapat mengetahui perkembangan membaca permulaan peneliti menggunakan Aspek membaca permulaan oleh slamet dalam implementasinya penilaian tes reading aloud/membaca nyaring dengan kriteria-kriteria membaca permulaan sebagai berikut. 1) lafal; 2) intonasi; 3) kelancaran; dan 4) kejelasan. ${ }^{23}$

Aspek pelafalan sudah berkembang dengan baik. Hal ini dapat diperhatikan dari hasil wawancara kepada guru bahwa kesulitan awal peserta didik terletak pada pelafalan dobel konsonan dan pelafalan huruf vokal ataupun konsonan yang mana pada peenelitian ini mulai berkurang dan menunjukkan hal yang positif.

Aspek intonasi mengalami juga perkembangan. Dari hasil wawancara kepada guru kesulitan awal pada tahap ini peserta didik kurang memperhatikan tanda koma dan tanda titik hal ini berpengaruh tidak ada jeda yang jelas saat membaca. Peserta didik mulai menujukkan perkembangan yang positif dengan peserta didik sudah mampu perlahan membaca menggunakan intonasi dan tanda baca yang tepat.

\footnotetext{
${ }^{22}$ Aminuddin, Prinsip-Prinsip Pembelajaran Terpadu dan Model Pembelajaran Bahasa Indonesia (Bandung: Sinar Baru, 1994), h. 117

${ }^{23}$ Slamet, St.Y, Dasar-Dasar Pembelajaran Bahasa dan Sastra Indonesia di Sekolah Dasar (Surakarta: UNS Press , 2007), h. 107.
} 
Muhammad Majdi : Pengembangan Keterampilan Membaca Siswa Madrasah Ibtidaiyah Kelas Rendah Menggunakan Picture Word Inductive Model

Aspek kelancaran juga mengalami perkembangan. Hasil wawancara dengan guru bahwa kondisi awal sebagian peserta didik perlu bimbingan guru dalam kegiatan membaca dan mengeja kata. Setelah pembelajaran ini peserta didik mulai menunjukkan perubahan yang utama adalah motivasi dan diiringi oleh keterampilan membaca yang berangsur membaik, sebagian peserta didik sudah mampu membaca dengan lancar walaupun temponya masih lambat dan sebagian juga masih mengeja namun peserta didik mengeja dengan lancar. Untuk mendapat hasil yang lebih baik maka kegiatan pembelajaran ini dilakukan secara continue/ berkelanjutan.

Aspek kejelasan. Dari hasil wawancara dengan guru kondisi awal peserta didik masih malu sehinggga suara yang dihasilkan kurang keras dan jelas. Perkembangannya peserta didik mulai memiliki kepercayaan diri yang baik berkat motivasi dan dorongan dari guru yang menyebabkan suara yang dihasilkan terdengar lebih keras dan jelas dari sebelumnya ketika diminta untuk membaca.

\section{Kesimpulan}

Pengembangan keterampilan membaca menggunakan Picture Word Inductive Model dapat mengembangkan kualitas pembelajaran keterampilan membaca permulaan bagi kelas 2 MIS Al Islamiyah Bangkar. Pada tahapan pembelajaran Picture Word Inductive Model oleh guru sudah berjalan baik dengan beberapa improvisasi pada kegiatan pembelajarannya. Tahap pertama pengenalan gambar guru menggunakan konsep gambar pop up yang menimbulkan minat dan motivasi peserta didik dalam mengikuti pembelajaran. Setelah itu peserta didik mengidentifikasinya dengan bersama-sama mengobservasi temuannya pada gambar sebagai bentuk pengalihan perhatian peserta didik agar terfokuskan. Dalam tahap ini peserta didik akan mendapatkan pengetahuannya sendiri. Setelah itu peserta didik mulai menyebutkan yang dilihatnya secara audio dan visual yaitu guru membaca dan peserta didik mengikutinya dan seterusnya peserta didik menyebutkannya sendiri yang secara visual dapat dilihat dari gambar pop up dengan menggunakan teknik membaca nyaring (reading aloud). Hal demikian akan menunjukan keaktifan peserta didik dalam mengikuti pembelajaran. Dari kata yang dihasilkan oleh peserta didik, guru mendampingi peserta didik untuk bersama-sama mengembangkannya menjadi sebuah kalimat sederhana. Kegiatankegiatan tersebut menunjukan keantusiasan peserta didik dalam menyebutkan kalimat sederhana yang dipikirkan. Kemudian guru menuliskannya di papan tulis.

Hasilnya dari langkah-langkah tersebut dapat sama-sama diketahui bahwa pembelajaran Picture Word Inductive Model dapat mengembangkan kualitas pembelajaran membaca permulaan pada kelas rendah. Pada aspek pelafalan dalam pelafalan dobel konsonan dan pelafalan huruf vokal ataupun konsonan yang menjadi kendala mulai berkurang dan menunjukkan hal yang positif. Aspek intonasi menujukkan perkembangan yang positif dengan peserta didik sudah mampu perlahan membaca menggunakan intonasi dan tanda baca yang tepat. Aspek kelancaran mengalami perkembangan. Sebagian besar peserta didik sudah mampu membaca dengan lancar walaupun temponya masih lambat dan sebagian juga masih mengeja namun peserta didik mengeja dengan lancar. Dan terakhir Aspek kejelasan peserta didik mulai memiliki 
Muhammad Majdi : Pengembangan Keterampilan Membaca Siswa Madrasah Ibtidaiyah Kelas Rendah Menggunakan Picture Word Inductive Model

kepercayaan diri yang baik sehingga menyebabkan suara yang dihasilkan terdengar lebih keras dan jelas. Jadi secara tidak langsung peserta didik yang memiliki keterampilan membaca rendah mulai berangsurangsur membaik dengan tindak lanjut secara continue dan berkelanjutan disetiap pembelajarannya. Sedangkan peserta didik yang sudah memiliki keterampilan membaca sedang dan tinggi dapat mengembangkannya lebih baik lagi.

\section{DAFTAR PUSTAKA}

Aminuddin, Prinsip-Prinsip Pembelajaran Terpadu dan Model Pembelajaran Bahasa Indonesia. Bandung: Sinar Baru, 1994.

Amir Tengku ramly, Proses Belajar Mengajar.Jakarta: Bumi Aksara, 2004.

Asih, Strategi Pembelajaran Bahasa Indonesia.Bandung: Pustaka Setia, 2016.

Benardi, Andi Irwan. Pendidikan Kesiapsiagaan Bencana Tanah Longsor Untuk Siswa Anak Usia Dini Dengan Metode Dongeng Berbasis Media Pop Up Book Di Paud Dewi Sartika Kecamatan Bergas. Jurnal., Portal Jurnal Elektronik UM: Jurusan Pendidikan Geografi: UM. 2017.

Bruce Joyce, Models of Teaching: Model-Model Pengajaran. Yogyakarta: Pustaka Pelajar, 2009.

Fahrurrozi, Pembelajaran Membaca Permulaan di Sekolah Dasar, Jurnal Ilmiah PGSD Vol. X No.2 Oktober 2016.

Henry Guntur Tarigan, Menulis: sebagai Suatu Keterampilan Berbahasa. Bandung: Angkasa, 1986.

Hertika Jeniar Litri, Implementasi Metode Reading Aloud Dalam Pembelajaran Membaca Permulaan Pada Siswa Kelas 2 SD, Jurnal Pendidikan Guru Sekolah Dasar Edisi 31 Tahun ke-5 2016.

Hisyam Zaini, dkk, Strategi Pembelajaran Aktif, Yogyakarta: Pustaka Insan Madani, 2008.

Isah Cahyani, Modul Pembelajaran Bahasa Indonesia. Jakarta: Direktorat Jenderal Pendidikan islam, 2012.

Ismail SM, Strategi Pembelajaran Agama Islam Berbasis PAIKEM (Pembelajaran Aktif, Inovatif, Efektif, dan Menyenangkan).Semarang: Rasail Media Group, 2008.

Joko Muktiono, Menumbuhkan Minat baca pada Anak. Jakarta: ElexMedia Komputindo, 2003.

Lalu kasiran, Penerapan Strategi Picture Word Inductive Model Guna Meningkatkan Hasil Belajar Dalam Menyusun Teks Deskriptif Berbahasa Inggris Bagi Siswa Kelas Vii/A Smp Negeri 3 Praya Tahun Ajaran 2014/2015, Jurnal Media Bina Ilmiah, Vol.12, No.11 Juni 2018.

Nana Syaodih Sukmadinata, Metode Penelitian Pendidikan, Bandung: Remaja Rosdakarya,2015.

Rachmawati, Pengembangan Model Induktif Kata Bergambar Pada Pembelajaran Menulis Permulaan Di Kelas Ii Sd, Sekolah Dasar, Tahun 24 Nomor 2, November 2015.

Siti Anisatun Nafi'ah, Model-Model Pembelajaran Bahasa Indonesia di SD/MI, Yogyakarta: Ar-Ruzz Media, 2018.

Slamet, St.Y, Dasar-Dasar Pembelajaran Bahasa dan Sastra Indonesia di Sekolah Dasar. Surakarta: UNS Press, 2007.

Solchan T. W.. dkk, Pendidikan Bahasa Indonesia di SD.Banten: Universitas Terbuka Press, 2014.

Sugiyono. Metode Penelitian Kualitatif untuk Penelitian yang Bersifat: Eksploratif Interaktif dan Konstruktif. Bandung: Alfabeta. 2017. 